This item was submitted to Loughborough's Research Repository by the author.

Items in Figshare are protected by copyright, with all rights reserved, unless otherwise indicated.

\title{
Regulating urban upgrading in developing countries
}

PLEASE CITE THE PUBLISHED VERSION

PUBLISHER

(C) Thomas Telford Publishing

LICENCE

CC BY-NC-ND 4.0

\section{REPOSITORY RECORD}

Jayaratne, K.A., and M. Sohail. 2019. "Regulating Urban Upgrading in Developing Countries". figshare. https://hdl.handle.net/2134/3885. 
This item was submitted to Loughborough's Institutional Repository (https://dspace.lboro.ac.uk/) by the author and is made available under the following Creative Commons Licence conditions.

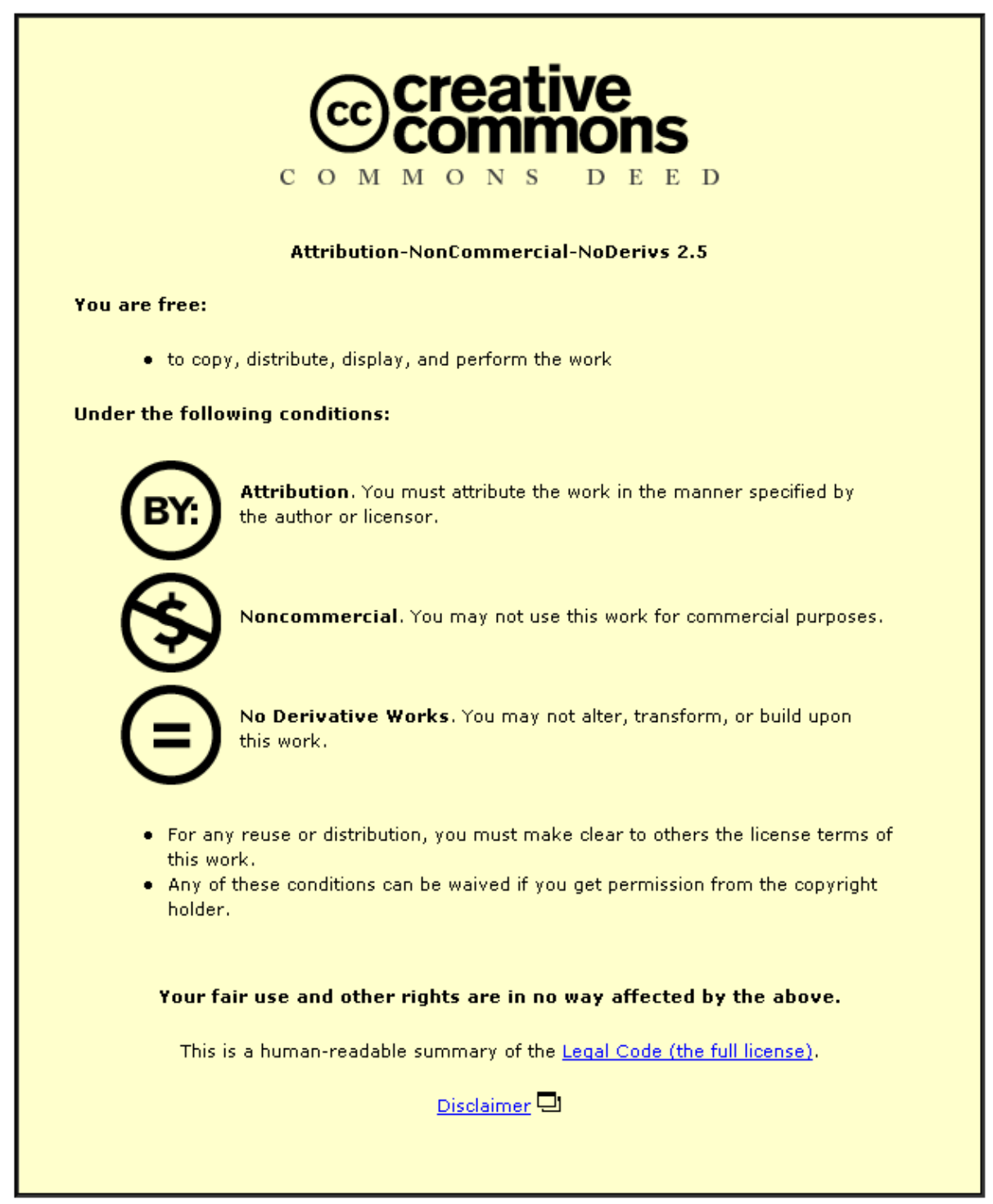

For the full text of this licence, please go to: http://creativecommons.org/licenses/by-nc-nd/2.5/ 


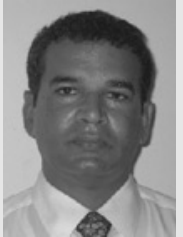

K. A. Jayaratne

President,

Urban Resources Centre Colombo, Sri Lanka

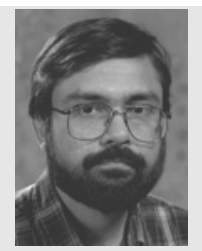

M. Sohail

Senior Research Manager,

Loughborough University,

UK

\section{Regulating urban upgrading in developing countries}

\section{K. A. Jayaratne and M. Sohail}

Drawing on a four-year research programme conducted in Sri Lanka (part of a larger programme also conducted in India and Kenya) this paper addresses the issue of building and planning regulations and how such regulations affect people's livelihoods. This paper begins by reviewing the urban housing programmes undertaken in Sri Lanka over the past 30 years with special reference to urban upgrading projects and their respective planning and building regulations. The authors have analysed four cases from Colombo Municipality and two cases from a secondary town, Moratuwa Municipality in Colombo Municipal Authority, in order to assess the impacts of such urban upgrading programmes on the livelihoods of the poor; some conclusions and recommendations have been drawn. Guidance notes (based on a literature review, historical analysis and case studies) are presented towards the end of the paper for the use of local government staff as well as others acting as partners in the improvement of livelihoods in urban areas. Land reforms and land management are key components of any sustainable urban upgrading programme. The authors conclude that regulatory frameworks which take into account existing patterns (with the exception of unsafe practices) of livelihoods and socio-economic aspirations will enhance the potential for sustainable livelihoods.

\section{INTRODUCTION}

Though city dwellers from low-income settlements (slums) in many developing countries contribute to the economic growth and social fabric of the cities, they are often not formally recognised or serviced adequately. ${ }^{1}$ Cities can become socially and economically more productive if the living conditions of low-income settlements are improved. The gravity of the challenge is such that one of the Millennium Development Goals is looking to improve the quality of life of the 100 million people living in slums by 2015. Despite the growing recognition that the urban poor, living in informal settlements, are an engine of growth and development, their assets and their innovations are still not recognised in land planning and building regulations. ${ }^{2}$ However, if such a large number of people do not exist in the formal frameworks of policymakers and planners, how can the lives of these people be improved?
Colombo is not just a beautiful city. It is a melting-pot of social experimentation and innovations in housing and urban infrastructure, which provided the authors with a long-term and rich perspective in relation to policy and practice. This paper is based on a research programme that the authors carried out to address the constraints imposed by exclusive and inappropriate regulations and procedures. Such regulations impact negatively on the livelihoods of the urban poor by constraining their accumulation of physical, human and social assets. ${ }^{3}$ The main objectives of the present study were to

(a) review the existing regulatory framework and legislation for regularisation and upgrading of low-income settlements

(b) study how the existing legislation affects poor people's livelihoods and their assets

(c) describe how local authorities in partnership with community-based organisations in urban areas have developed regulatory guidelines for urban upgrading

(d) assist local authorities and communities to improve their capacity by revising and developing a pro-poor regulatory framework.

Although the primary data are drawn from Colombo, the findings have a general resonance and application in the cities of other developing countries.

This paper investigates the hypothesis that the urban poor are unable to achieve sustainable livelihoods because policy and regulatory frameworks not only constrain their access to assets and opportunities, they also prevent low-income groups from engaging in activities that would otherwise enable them to make a living. ${ }^{4}$ The authors also explore how people cope within a given regulatory framework. It will be concluded that the pace of development can be greatly improved if regulatory frameworks can be developed that give due recognition to the contributions already made by the inhabitants of low-income settlements.

\section{THE CITY OF COLOMBO}

Although it has been the capital city of Sri Lanka for over a century, Colombo's total population has yet to reach one million. The city's administrative area of $37.31 \mathrm{~km}^{2}$ is grouped into 47 municipal wards and six administrative districts. Colombo's economy is based around the activities of its harbour. 


\begin{tabular}{|lccccc|}
\hline Nature of housing & $\begin{array}{c}\text { No. of } \\
\text { settlements }\end{array}$ & $\begin{array}{c}\text { No. of } \\
\text { families }\end{array}$ & $\%$ \\
\hline $\begin{array}{l}\text { Settlements with } \\
\text { permanent housing } \\
\text { over 50\%, two-storeyed }\end{array}$ & 404 & 26 & 18033 & 23 \\
$\begin{array}{l}\text { Settlements with } \\
\text { permanent housing } \\
\text { with over 50\%, } \\
\text { single-storeyed } \\
\text { Settlements with } \\
\text { semi-permanent housing }\end{array}$ & 881 & 54 & 36411 & 47 \\
$\begin{array}{l}\text { Settlements with } \\
\text { temporary housing }\end{array}$ & 231 & 14 & 14418 & 19 \\
$\begin{array}{l}\text { Total } \\
\text { Table I. Housing conditions in low-income settlements }\end{array}$ & 98 & 6 & 8750 & 11 \\
in Colombo, 2002 12 & 1614 & 100 & 77612 & 100 \\
\hline
\end{tabular}

Of particular interest to researchers is the fact that Colombo has managed to improve the living conditions of its urban poor significantly over the past 30 years. ${ }^{5,6}$ During the 1970 s half the city's population were living in poorly serviced and environmentally degraded slums and shanties. ${ }^{7,8}$ With the assistance of central government and donor agencies, Colombo Municipality implemented several programmes to improve the health, basic services and housing conditions of these communities. ${ }^{9-11}$ As a result, almost all these settlements now have their own community-based organisations, while more than $60 \%$ of households have legal tenure or leasehold rights for land and have improved their housing situation (see Table 1). ${ }^{12}$

\section{IDENTIFICATION OF SETTLEMENTS AT URBAN LOCAL AUTHORITY LEVEL}

A policy paper entitled The Slums and Shanty Improvement Programme was published by the Ministry of Local Government Housing and Constructions in 1979. ${ }^{13}$ It identified four types of low-income settlements in the city of Colombo.

(a) Slums or subdivided derelict houses, built mostly of permanent materials, are very often single-roomed and compactly arranged in back-to-back rows. A cluster of tenement units with a definite property boundary is called a 'tenement garden'; it shares common amenities, which are often insufficient and badly maintained. The occupants have a definite legal status in terms of their occupancy.

(b) Shanties are impoverished and unauthorised shelters constructed by urban squatters on state- or privately-owned land; they do not have any legal right of occupancy. Such areas are badly serviced and often unsanitary.

(c) Unserviced semi-urban neighbourhoods are badly serviced residential areas in the suburban areas of Colombo and in the district towns. They are characterised by impoverished structures and/or shelters built with traditional, often rural-type, methods and materials. In contrast to squatter areas, the occupants have definite legal titles or leasehold rights for the land.

(d) Local authority labour lines (living quarters) are derelict housing areas belonging to local authority or government agencies, which are unable to maintain the quality of housing owing to lack of finances and property management problems. These units often house municipal or government workers such as scavengers or casual labourers. The employment status and nature of the work of the occupants are the main reasons why these housing areas do not arouse official concern.

Since 1978 Colombo Municipal Council (CMC) has been carrying out innovative shelter-upgrading programmes with the help of central government and external support agencies to improve the living conditions of slum/shanty-dwellers in the city. These programmes include

(a) provision of basic services for improvement of environmental health

(b) innovative laws and procedures related to planning and construction of affordable infrastructure and housing for the poor

(c) support-based housing policies to improve the quality of housing stock through self-help

(d) promotion of participatory approaches to develop community organisations and livelihood means.

Each of these programmes has contributed to secure land ownership and the gradual improvement of housing and livelihood means for slum and shanty dwellers. The programmes are implemented within a regulatory framework. Since 1915 a number of laws relating to housing and urban development have been enacted; some laws are supportive for urban upgrading but many are not. On many occasions laws are defined and enacted as instruments for controlling physical development and enforced to discourage self-help efforts and community initiatives. Nonetheless, under certain urban development programmes in the 1980s, guidelines were developed and implemented in Sri Lanka in a participatory manner for land regularisation, house construction and infrastructure improvement in poor areas. This had an impact on the quality of life of the poor as well as the general environment of the city. Unfortunately, such innovative guidelines have not been legally adopted as procedures or by-laws by the local government system.

\section{METHODOLOGY}

The main question explored in this research was how regulatory regimes interact with the livelihoods of dwellers in informal settlements. The research involved a literature review (including a review of relevant regulations), case studies and stakeholder workshops. The research was based on the sustainable livelihoods framework. ${ }^{14}$ The framework describes poverty reduction as a process through which the vulnerability of the poor is reduced while at the same time increasing those people's capacity to acquire skills, productive assets and other resources in order to be more able to face sudden and unexpected disasters, shocks and losses. Six upgraded settlements were selected, four within Colombo municipality area and two from Moratuwa, these being

(a) Kalinga Mawatha Shanty Upgraded Settlement

(b) Bo Sevana Shanty Upgraded Settlement

(c) Seevalipura Shanty Upgraded Settlement

(d) Swanrna Road Shanty Upgraded Settlement

(e) Siribara Pura Menike Upgraded Settlement in Moratuwa MC

(f) Jayagathpura Upgraded Settlement in Moratuwa MC. 


\section{REGULATORY FRAMEWORKS}

Regulatory frameworks include laws, ordinances, legislation, regulations, licences, contracts and/or similar instruments that define acceptable conduct in relation to town planning, public health, land development and construction and are administered and enforced by regulatory bodies. In 1985 the United Nations Centre for Human Settlements (UNCHS) ${ }^{15}$ made the following definitions.

(a) Building regulations are a set of detailed regulations to control the construction of buildings; these are statutory and must be complied with.

(b) Building codes are a set of practical technical and administrative non-mandatory rules and requirements for the construction of buildings.

(c) Building acts as a government enactment, authoritative decree or law of regulation to control physical development of the built environment. Building acts can only be amended by legislative authority and are statutory in effect.

Building acts, regulations and codes are designed to: ensure safety in construction (damage to structures, fire, natural disasters or risks to construction workers); health in the built environment; legal control in the construction industry; and to provide technical guidance on standards and specifications for building materials and town planning rules and regulations.

\section{AN HISTORICAL PERSPECTIVE OF REGULATORY FRAMEWORKS AND PROGRAMMES IN SRI LANKA}

The following subsections provide a brief review of regulatory frameworks within the context of legislation from 1915 to 1999 with regard to urban low-income communities in Colombo.

\section{I. The Housing and Town Improvement Ordinance of 1915}

The Housing and Town Improvement Ordinance of 1915 prescribed a set of planning and building rules. It does not enable the urban poor to protect their productive assets for continuing their livelihoods. These planning and building rules are used mainly to control, administer or regulate the following aspects of buildings
(a) height in proportion to the width of existing streets
(b) reservation of a proportion of the site as open space
(c) size and ventilation of inhabited rooms
(d) open-air spaces at the side or interior of buildings
(e) open space to the rear of buildings
$(f)$ access from single-room tenements to the street.

\subsection{Enactment of the Ceiling on Housing Property Law No. I, 1973 (CHP Law)}

Serious housing shortages as well as the deteriorating conditions in the slums and shanty settlements were the main causes for the government to introduce the CHP Law in 1973. By introducing this law, the government granted permission to exist to slum and shanty dwellers which led to a sense of ownership of the property that in turn encourages improvement to housing on a self-help basis. Consequently, more than 12000 tenants living in slums became home-owners of their rental housing under this law.
6.3. UNICEF-assisted Urban Basic Services Improvement Programme (UBSIP), 1978- 1986

In 1970 CMC and the Common Amenities Board (CAB), under the Ministry of Local Government Housing and Construction and with financial support from UNICEF, implemented the UBSIP. This programme provided common toilets, street taps, common bathing places, storm-water drains and community centres for low-income communities. In order to get the urban poor to participate in the improvement activities, UBSIP assisted CMC to form Community Development Councils (CDCs) in slums and shanty settlements. As a result of the UBSIP intervention nearly 600 CDCs are functioning in the city up to the present day. ${ }^{1}$ CDCs have been important community-based organisations in subsequent programmes and projects implemented in Colombo for poverty reduction. Nearly 600 CDCs are currently functioning in the city.

\subsection{Slums and Shanty Improvement Programme (SSIP), 1978- 1984}

The Urban Development Authority (UDA) initiated the Slums and Shanty Improvement Programme (SSIP) in 1978. Under the SSIP, a comprehensive slums and shanty improvement programme was planned and implemented in urban local authority areas. It had introduced on-site upgrading, site and service projects and basic service improvement projects. ${ }^{2}$ The SSIP prepared a set of minimum standards affordable to low-income communities in the provision of services for low-income people.

\subsection{Major housing development programmes implemented by the National Housing Development Authority (NHDA) since 1978}

The National Housing Development Authority (NHDA) has implemented several housing programmes, the most innovative and community-centred being the Million Houses Programme implemented from 1984 to 1989. During this time low-income settlements in Colombo city were identified for the implementation of the programme. Upgrading policies, planning standards and regulatory guidelines tested under the SSIP formed the basis of the design and implementation of the Urban Housing Sub-Programme (UHSP) with the support of urban local authorities (ULAs). The upgrading package consists of the following components: land tenure; basic infrastructure services; financial assistance for self-help housing; and assistance for community-based organisation strengthening and social development activities. The impact of the programme on the poor's livelihoods in the urban areas has been significant. People in upgraded settlements are no longer considered totally illegal citizens. Community-based organisations (especially CDCs) have become recognised institutions at the grassroots level for the improvement of basic services.

\section{GUIDANCE POINTS FOR MUNICIPAL ENGINEERS}

The second half of this paper presents the findings on community-based urban upgrading from the six settlements selected as case studies for this research.

According to the UDA Amendment Act No. 4 of 1982, any lowincome settlement or site can be declared a Special Project Area for the purposes of applying relaxed standards for settlement upgrading. Relaxed standards allow the Planning and Building 
Regulations applicable under the Housing and Town Improvement Ordinance of 1915, Town and Country Planning Ordinance of 1945 and UDA Law to be changed, but only for the projects located within the Declared Special Project Area. Further edicts include the following.

(a) Urban upgrading should be part of urban development and poverty reduction policies.

(b) Local authorities have planning and regulatory powers to prepare and implement the regulatory guidelines developed through participatory processes for urban upgrading.

(c) In order to ensure the Regulatory Guidelines for Urban Upgrading are recognised legally and to transfer some regulatory functions to community-based organisations, the local authority should formally approve Regulatory Guidelines for Urban Upgrading.

(d) The declaration of slums and shanty communities as special project areas for urban upgrading and the key stakeholder's participation in workshops, concerned for the development of upgrading guidelines, needs to be institutionalised at local authority level.

\section{DEFINITION OF AN UPGRADEABLE SETTLEMENT}

Informal low-income settlements where in situ (on-site) upgrading is feasible are called 'upgradeable settlements'. If an informal settlement is to qualify for in situ upgrading it must meet the following criteria.

(a) The settlement should be located within an area that is suitable for human habitation.

(b) A majority of the households should have an established means of livelihood at this current location.

(c) The settlement should not be in an area where

(i) the land falls within a high security-risk zone, which creates constraints for free movement of the community

(ii) future development will be affected directly or indirectly under the compulsory land requirements of special legislation.

(d) The land area should be sufficient to accommodate the majority of households on an agreed layout and with basic infrastructure services.

(e) Settlements on government land are better for in situ upgrading than others because taking over possession of the land is straightforward.

( $f$ ) Settlements should have little or no inconsistencies with the overall development plan of the city/town.

\section{WHAT IS AN UN-UPGRADEABLE SETTLEMENT?}

Informal low-income settlements where in situ (on-site) upgrading is not feasible are called 'un-upgradeable settlements'. If a settlement has the following characteristics, it can be identified as an un-upgradeable settlement.

(a) Settlements that are located in areas not suitable for human habitation, for example flood-prone areas or narrow reservations along roads.

(b) Settlements that have major inconsistencies with the overall development plan of the city/town in terms of its residential and/or commercial use. (c) Settlements located in areas of very high land value. Market forces will convert such areas into non-residential uses, pushing the poor away.

(d) Settlements located in high security-risk zones where people are not allowed to move freely and in areas where land can be used only for a special purpose as stipulated in legislation (irrigation or coast conservation, for example).

Temporary upgrading or resettlement can be applied to settlements that cannot be upgraded in situ.

\section{I0. UPGRADING STEPS}

A step-by-step guide to the upgrading process, based on the experience of community projects in Colombo and Moratuwa Municipal Areas, is summarised in the subsections below (see Fig. 1).

\section{I. Declaration of 'special project areas'}

The first step of the upgrading process is the declaration of urban shelter upgrading projects as Special Projects Areas under the UDA (Amendment) Act No. 4 of 1982. The request for such a declaration has to be submitted by the local authority to the UDA or to the ULA's planning committee for prior approval.

\subsection{Selection of priority settlements for upgrading}

The ULA's planning committee consults the Housing and Community Development Committee (HCDC)* to select priority settlements and the sites for upgrading. Settlements selected for upgrading by the HCDC are submitted to the ULAs for planning approval. The following are criteria for selection of priority settlements for upgrading.

(a) Communities most deficient in services and livelihood opportunities.

(b) Settlements on public land to be chosen first to avoid procedural delays in taking over the possession of private land.

(c) Settlements that have little or no inconsistencies with the overall development plan.

(d) Low-income settlements where people have already taken initiatives for upgrading.

\subsection{Community mobilisation process}

As communities are going to be involved actively in the formulation and implementation of regulatory guidelines for urban upgrading, they need to be organised and empowered through a mobilisation process. Key features of the community mobilisation process are as follows.

(a) Community identification. The first stage of the mobilisation process is carried out in three steps by the

*HCDC is a committee established for monitoring of activities and policy issues related to housing and community development activities in ULA. The committee meets monthly and is chaired by the mayor. It consists of officials of the ULA, civil society representatives and relevant government officials. 


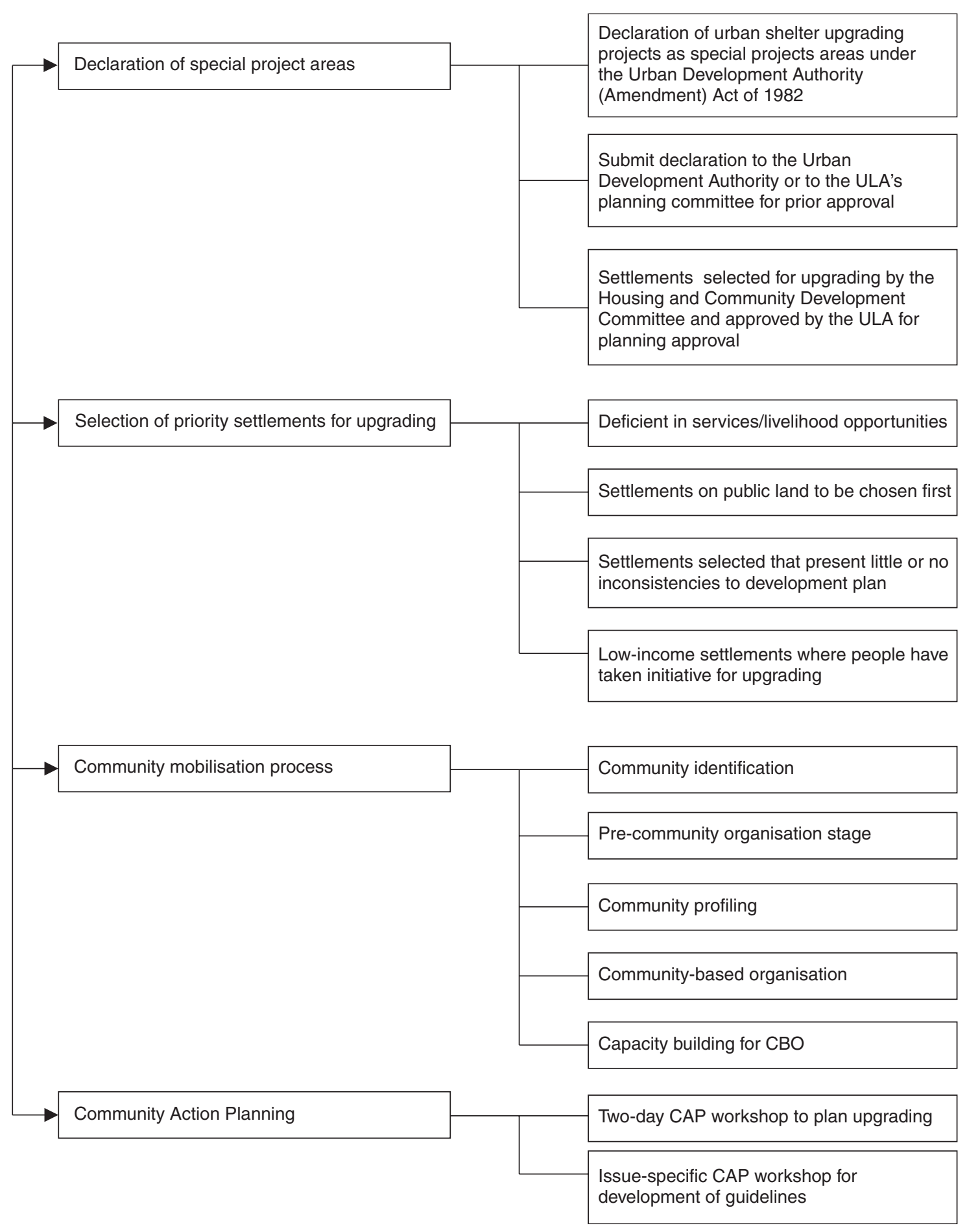

Fig. I. The process of developing people-centred regulations

project-implementing agency; ${ }^{\dagger}$ preparation of a settlement profile, establishment of a Community Development Committee, ${ }^{\ddagger}$ and evaluation of existing community-based organisations in the settlement.

\footnotetext{
${ }^{\dagger}$ Project Implementing Agency can be a central government and/or local government agency. A non-governmental organisation (NGO) can act as a partner organisation for the implementing agency.

${ }^{\ddagger}$ It is a committee of important people of the area to advise and guide community-based organisations for development activities.
}

(b) Pre-community organisation stage. Community meetings are conducted to explain the community participation and the upgrading process.

(c) Community profile. Information collected by community representatives through a self-assessment process will form the basis of the community profile.

(d) Community-based organisation formation. The CDC and other community-based organisations (CBOs) such as Employees Federation or Women's Savings and Credit groups were the two important community-level organisations instrumental in procurement and operation and maintenance (O\&M) of infrastructure in the case-study settlements. 
(e) Community-based organisation capacity building. Elected CBO members need to know how CBOs are run effectively; therefore, capacity building of the $\mathrm{CBO}$ has to be done at this stage. Capacity building includes not only training of CBO members but also improvement of systems and procedures of CBO operations. In particular, women's capacity was built in Bo Sevana where women's savings and credit groups of the settlement had supported the CDC in implementation of the programme. It has been found in projects implemented under the UHSP of the Million Houses Programme, as well as pilot projects carried out under the Water, Engineering and Development Centre (WEDC) research by Sevanatha, that community mobilisation is an essential part of the urban upgrading process.

\subsection{Community action planning process}

Regulatory guidelines applicable to upgrading projects implemented under the Million Houses Programme have been developed through a participatory process. The participatory tool used is called Community Action Planning (CAP). The tool provides for the participation of stakeholders throughout the upgrading process. In particular the CAP is designed to motivate and mobilise men and women in urban settlements to take the lead in design, implementation and evaluation of community development projects and in their own initiatives in livelihood improvement. CAP is done in a workshop arrangement at community level by the participation of key stakeholders involved in the upgrading process. Two types of CAP workshops-one on overall planning and another on thematic issues-are held in communities in order to develop action plans for urban upgrading.

10.4.1. Two-day CAP workshop. The process starts with a two-day CAP workshop which aims to prepare a development programme for the settlement. Typically, meetings are held in the settlement. A representative group from the community, officials from the local authority, NHDA, UDA and non-government organisations (NGOs) participate in the workshop. Half of the community representatives were aimed to be women. In all, about 40 to 50 stakeholders participate in the workshop. In order to prepare an upgrading plan for the settlement, participants are divided into groups to

(a) identify issues and analyse them

(b) identify solutions and priorities

(c) identify alternative strategies for achieving solutions

(d) select suitable strategies

(e) prepare an action plan, which consists of the following components: problems; solutions; strategy; responsibilities (who does); finance (who pays); when activities start; how and who does the follow-up; O\&tM issues

(f) prepare an appropriate monitoring mechanism

(g) implement CAPs.

At the end of the two-day CAP workshop, a settlement-based plan is ready for implementation. However, during implementation, communities will almost certainly face certain issues that need to be discussed in detail and agreed collectively-such as the what, how, who and when scenarios. Whenever such an issue is presented, officials and community members hold Thematic Community Workshops to develop commonly agreed solutions. The end results of these specific workshops are guidelines and action plans for implementation of agreed solutions.

\subsubsection{Theme (issue)-specific CAP workshop. Theme-} based CAP workshops are generally conducted for the development of the following aspects of the upgrading process.

(a) Basic planning principles for land regularisation (see Table 2).

(b) Detailed technical guidelines for land subdivision, house building, infrastructure construction (see Table 3).

(c) Procedures for community contracting, community-based organisation strengthening, community enterprise operation, infrastructure 0\&M.

(d) Deciding roles and responsibilities of stakeholders involved in the upgrading process.

Theme-specific CAP workshops are organised by the project-implementing organisation. These workshops are structured in such a way that community groups meet with officials and discuss and decide what are the issues related to the upgrading process. A representative group from the community take part in the workshop and are assisted by technical officers from the local authority and government agencies such as the NHDA. Representatives of NGOs working in the settlements (if any) are also invited to attend.

Analysis of successful upgrading projects set up in Colombo reveal that the planning principles and technical guidelines formulated for land regularisation in community workshops have indeed been implemented. Such principles typically include the following.

(a) Criteria for plot allocation, such as

(i) one regularised plot per shanty unit

(ii) one regularised plot per family

(iii) one regularised plot per household.

(b) Minimum disruption to existing structures.

(c) Maximum retention of existing structures.

(d) Permanent structures and places of economic and social benefit to the community should be retained.

(e) Existing settlement pattern should be preserved as much as possible.

( $f$ ) Bona fide residents, whether permanent residents or renters, are entitled to a plot.

(g) All plots should fall within a minimum and a maximum range of sizes.

(h) Each and every housing plot must have access to a public road or a footpath and other public utilities.

(i) Land-use regulations to be flexible and permit most non-hazardous or environmentally friendly uses.

\subsection{Implementation}

Table 4 gives the roles and responsibilities for key actors involved in the implementation of Community Building Guidelines developed in CAP workshops held in Colombo. 


\begin{tabular}{|c|c|c|}
\hline Issue & Guideline & Rule \\
\hline Minimum plot size & - & $50 \mathrm{~m}^{2}$ \\
\hline $\begin{array}{l}\text { Boundary line and } \\
\text { boundary marker }\end{array}$ & Owner should be aware and protect it & $\begin{array}{l}\text { No person can fix or move it without ULA } \\
\text { permission }\end{array}$ \\
\hline $\begin{array}{l}\text { Who should prepare } \\
\text { house plan? }\end{array}$ & $\begin{array}{l}\text { - Householder and/or } \\
\text { - Builder or a draughtsman or } \\
\text { - Officer from Project Implementing agency }\end{array}$ & $\begin{array}{l}\text { All house plans must be approved by the } \\
\text { officer assigned to project by ULA or } \\
\text { Project Implementation agency }\end{array}$ \\
\hline House design & $\begin{array}{l}\text { Space should be allocated for living, sleeping, } \\
\text { working, toilet, bath and home compost bin }\end{array}$ & $\begin{array}{l}\text { Space kept for different functions should be } \\
\text { shown in the house plan }\end{array}$ \\
\hline Front space & $\begin{array}{l}\text { No structure should project over the plot } \\
\text { boundaries }\end{array}$ & $\begin{array}{l}\text { Minimum of I } \mathrm{m} \text { space from the front } \\
\text { boundary should be kept bare }\end{array}$ \\
\hline Rear space & $\begin{array}{l}\text { - No structure should project over plot } \\
\text { boundaries } \\
\text { - Minimum of } 1.2 \mathrm{~m} \text { space between rear } \\
\text { boundaries of houses should be kept for } \\
\text { service lines/O\&M }\end{array}$ & $\begin{array}{l}\text { Minimum of I } \mathrm{m} \text { from rear boundary should } \\
\text { be kept bare }\end{array}$ \\
\hline Waste water & $\begin{array}{l}\text { - Householder should dispose of waste water } \\
\text { from kitchen and bathrooms without } \\
\text { bothering neighbours } \\
\text { - Connect to sewer lines }\end{array}$ & $\begin{array}{l}\text { Waste water must be run off to the front and } \\
\text { rear drains }\end{array}$ \\
\hline Rain water & $\begin{array}{l}\text { Prevent overflow of rain water on to } \\
\text { neighbour's plot }\end{array}$ & $\begin{array}{l}\text { - Slope of roofs must be to front and rear } \\
\text { of houses } \\
\text { - Rain water should not flow on to } \\
\text { neighbour's plot }\end{array}$ \\
\hline Ventilation and light & $\begin{array}{l}\text { - Each room must have adequate light and } \\
\text { ventilation } \\
\text { - Vent opening to front and rear walls } \\
\text { - If above options not possible put glass sheets } \\
\text { in the roof } \\
\text { - Raise part of roof for ventilation }\end{array}$ & $\begin{array}{l}\text { Minimum height from the floor to the wall } \\
\text { plate must be } 2.1 \mathrm{~m}\end{array}$ \\
\hline Smoke & $\begin{array}{l}\text { - Prevent kitchen smoke coming into house } \\
\text { - Common walls should be raised up to roof to } \\
\text { prevent the leakage of smoke }\end{array}$ & $\begin{array}{l}\text { - Smoke house and chimney must be } \\
\text { provided if there is an internal hearth } \\
\text { - Smoke must not go into the neighbouring } \\
\text { house }\end{array}$ \\
\hline Side boundaries & $\begin{array}{l}\text { Common walls can be constructed on the side } \\
\text { boundaries }\end{array}$ & $\begin{array}{l}\text { - Windows should not open into } \\
\text { neighbouring house. } \\
\text { - Side walls should not be constructed on } \\
\text { neighbour's land }\end{array}$ \\
\hline Roof & $\begin{array}{l}\text { - An adequate slope to the roof in keeping } \\
\text { with materials } \\
\text { - Suggested roof slopes are } \\
\text { for tiles: } 30^{\circ} \\
\text { for asbestos: } 12-15^{\circ} \\
\text { for Gl sheets: } 12-15^{\circ}\end{array}$ & $\begin{array}{l}\text { No part of the roof should extend beyond } \\
\text { the plot boundaries }\end{array}$ \\
\hline
\end{tabular}

\subsection{Operation and maintenance of services}

It was important to note that the case study communities have taken their own initiatives for OAtM of the community-level infrastructure. A majority of households in the case study settlements have been willing to contribute money and labour when the need arises for carrying out OAM activities of their services. The case study communities also have shown interest in obtaining the assistance of ULAs in carrying out O\&tM of services. Further possibilities exist for promoting partnership between the communities and the ULA for OAM of services in low-income settlements. In particular, youth and women have benefited from skill development activities related to O\&tM of services, which might lead to income-generating opportunities.

However, there are also a number of constraints to a sustainable octM process in low-income settlements, such as

(a) political interference demotivating community initiatives

(b) legal responsibilities of ULAs in O\&M (c) institutional and information gaps between the CBOs and ULAs

(d) no proper coordination between ULA and project implementing agencies

(e) insecure land tenure.

\section{CONCLUSIONS AND RECOMMENDATIONS}

Urban upgrading has been carried out in almost all ULA areas in Sri Lanka over the past 20 years. Most of the upgrading projects carried out in Colombo have improved the community livelihoods and basic infrastructure in poor areas. As a result, communities have acquired various productive assets and these are now creating regular income for families who were once considered squatters or slum dwellers. The fieldwork also highlighted that proper upgrading of low-income, informal settlements not only provides adequate housing, water supply and sanitation facilities, it also helps communities to reduce their level of vulnerability to natural calamities and economic and social problems. Regulatory frameworks that take into 


\begin{tabular}{|c|c|c|}
\hline Issue & Guideline & Rule \\
\hline Plot size & $\begin{array}{l}\text { Average } 65 \mathrm{~m}^{2} \\
\text { Minimum } 50 \mathrm{~m}^{2}\end{array}$ & Minimum $50 \mathrm{~m}^{2}$ \\
\hline Plot shape & Rectangular is appropriate & \\
\hline Plot frontage & Average $6 \mathrm{~m}$. Minimum $5 \mathrm{~m}$ & Minimum $5 \mathrm{~m}$ \\
\hline Type of layout & Linear, cluster & - \\
\hline $\begin{array}{l}\text { Average number of } \\
\text { plots per cluster }\end{array}$ & $5-10$ & - \\
\hline $\begin{array}{l}\text { Width of the private } \\
\text { spaces of a plot }\end{array}$ & $\begin{array}{l}\text { Rear, minimum of I } \mathrm{m} \\
\text { Front, minimum of I } \mathrm{m}\end{array}$ & $\begin{array}{l}\text { Rear, minimum of I } \mathrm{m} \\
\text { Front, minimum of } \mathrm{I} \mathrm{m}\end{array}$ \\
\hline Service space & $\begin{array}{l}\text { Minimum of I } \mathrm{m} \text { to rear, in addition to } \\
\text { private space }\end{array}$ & - \\
\hline Type of infrastructure & $\begin{array}{l}\text { - Off-site } \\
\text { - Common (within settlement) } \\
\text { - On-site (private plot) }\end{array}$ & On-site (private plot) \\
\hline Road system & Loop system & - \\
\hline Road width & $\begin{array}{l}\text { Vehicular road widths, minimum } 4 \mathrm{~m} \\
\text { Access roads, minimum } 2 \mathrm{~m}\end{array}$ & $\begin{array}{l}\text { Vehicular road, minimum } 4 \mathrm{~m} \\
\text { Access roads, minimum } 2 \mathrm{~m}\end{array}$ \\
\hline Sanitation & $\begin{array}{l}\text { Short-term, common toilets } \\
\text { Long-term on-site private }\end{array}$ & $\begin{array}{l}\text { Short-term, common toilets } \\
\text { Long-term on-site private }\end{array}$ \\
\hline Drains & $\begin{array}{l}\text { Sufficient space will be kept in regularisation } \\
\text { plan for network of drains for stormwater } \\
\text { and wastewater discharge. Each plot will } \\
\text { have access to the drainage network of } \\
\text { the settlement }\end{array}$ & $\begin{array}{l}\text { Sufficient space will be kept in regularisation } \\
\text { plan for network of drains for stormwater } \\
\text { and wastewater discharge. Each plot will } \\
\text { have access to the drainage network of } \\
\text { the settlement }\end{array}$ \\
\hline Garbage disposal & $\begin{array}{l}\text { Sufficient space should be kept for a } \\
\text { compost yard and a recyclable material } \\
\text { collection centre }\end{array}$ & $\begin{array}{l}\text { Sufficient space should be kept for a } \\
\text { compost yard and a recyclable material } \\
\text { collection centre }\end{array}$ \\
\hline Public spaces & $\begin{array}{l}\text { If there is sufficient land available, space } \\
\text { should be kept for a community centre } \\
\text { and recreation }\end{array}$ & - \\
\hline
\end{tabular}

\begin{tabular}{|c|c|}
\hline Key actors & Role and responsibility \\
\hline House builder & $\begin{array}{l}\text { Participate in the Community } \\
\text { workshop, draw the house plan } \\
\text { according to the Community } \\
\text { Building Guidelines, obtain } \\
\text { approval from community- } \\
\text { based organisation and ULA } \\
\text { and provide a copy to } \\
\text { community-based organisation }\end{array}$ \\
\hline $\begin{array}{c}\text { Community-based } \\
\text { organisation }\end{array}$ & $\begin{array}{l}\text { Organise community workshop, } \\
\text { distribute Community Building } \\
\text { Guidelines to householder, } \\
\text { check house plan before } \\
\text { submission to ULA, assist } \\
\text { house builder to obtain ULA } \\
\text { approval, inform ULA about } \\
\text { householders who do not } \\
\text { observe Community Building } \\
\text { Guidelines }\end{array}$ \\
\hline $\begin{array}{r}\text { Urban local } \\
\text { authority }\end{array}$ & $\begin{array}{l}\text { Hold community workshop with } \\
\text { beneficiary families, submit } \\
\text { Community Building Guidelines } \\
\text { for HCDC approval, check } \\
\text { house building and if necessary } \\
\text { impose sanctions }\end{array}$ \\
\hline
\end{tabular}

account existing patterns of livelihoods and socio-economic aspirations will enhance the potential for sustainable livelihoods.

However, urban upgrading is still not recognised as a means to solve many urban problems under conventional city planning processes. Therefore, based on the evidence, the authors recommend that urban upgrading should be mainstreamed in the planning cycle through a set of guidelines approved by the relevant authorities. There is a need to develop tools, methods and systems that are appropriate for sustainable 0\&M of services in urban low-income settlements.

\section{I.I. Key considerations for municipal engineers}

Land reforms and land management, as the key to unlock contributions from city dwellers, are a vital component of any sustainable urban upgrading. The following are the key guiding considerations for engineers involved in upgrading informal, low-income settlements, based on the experience of ULA areas in Sri Lanka. These principles should be non-negotiable in respect of the project implementation.

(a) Prior to project implementation all communities should be given information regarding the regulatory guidelines in a form that they can understand.

(b) Guidelines should be considered as a dynamic, continuing process.

(c) A real partnership should exist between the community and the local authority throughout the planning/development process. 
(d) Private-sector participation, including participation by NGOs, should be encouraged.

(e) Upgrading should be based on the sustainable livelihoods framework $^{\S}$ whereby no community is excluded from the upgrading process.

(f) While the government is playing the role of enabler, regulatory functions should be decentralised to actors at the local level.

(g) Community-based organisations should be considered as local-level institutions for the implementation of Regulatory Guidelines for urban upgrading.

(h) Training courses should be prepared for municipal managers, local government and NGOs on community procurement procedures.

(i) Attention should be given to the land title problem in urban low-income settlements.

(j) Upgrading programmes should be accompanied by parallel programmes dealing with the urban growth issue to prevent the proliferation of slums.

\section{II.2. Themes for further research}

Some themes that need further exploration include

(a) solidarity/community resistance to eviction ${ }^{16,17}$

(b) self-help and incremental house building as important ways for the poor to secure decent housing ${ }^{18-23}$

(c) ways to increase government capacity for monitoring and planning settlements ${ }^{24-26}$

(d) the problem of middle-class capture of the housing for the poor

(e) the role of middlemen in land acquisition

(f) social capital and a more holistic approach to improve housing $^{27,28}$

$(g)$ the gendered effects of regulations ${ }^{29}$

(h) the impact of national economics on policies addressing informal settlements ${ }^{30,31}$

(i) the question of whether to 'hire in' skilled people for house building/construction or whether local communities should try to acquire those skills themselves ${ }^{32}$

$(j)$ the promotion of traditional materials and traditional skills

$(k)$ whether or not the housing deficit of a country is a result of building regulations rather than an actual housing shortage.

\section{I2. ACKNOWLEDGEMENTS}

This paper is based on a part of an international research project supported by DFID-KAR. The case studies were undertaken in: Mumbai (India), Colombo (Sri Lanka) and Mavoko (Kenya). The project partners included ITDG UK, ITDG-EA in Kenya, Homeless International and SPARC in India, WEDC and Sevanatha in Sri Lanka. The authors are greatly indebted to numerous people in the low-income settlements. The opinions expressed are not necessarily those of the sponsors or the partners.

\footnotetext{
${ }^{\S}$ The framework describes poverty reduction as a process through which the vulnerability of the poor is reduced while at the same time increasing those people's capacity to acquire skills, productive assets and other resources in order to be more able to face sudden and unexpected disasters, shocks and losses.
}

\section{REFERENCES}

1. Rao P. S. N. Urban basic services-need for emphasis on houseless poor. Nagarlok, 1995, 27, Part 4.

2. YAsini P. A. Urban Planning Standards and Guidelines in Developing Countries. MSc thesis, Water, Engineering and Development Centre, Loughborough University, 1993.

3. BERNER E. Poverty alleviation and the eviction of the poorest; towards urban land reform in the Philippines. International Journal of Urban and Regional Research, 2000, 24.3, September.

4. REID M. Business regulations and poor entrepreneurs in urban India. Small Enterprise Development, 1993, 4, No. 1.

5. Sevanatha-Urban Resource Centre. Urban Poor in Colombo, Sri Lanka-Status and Directions for Development. Sevanatha, Sri Lanka, 1999.

6. Sevanatha-Urban Resource Centre. Gajabapura-Bo Sevana Community Managed Sewer System. Sevanatha, Sri Lanka, 1995.

7. Chularathna H. M. U. Land Tenure Issues and Improvement of Urban Low Income Settlements: the Experience of Colombo, Sri Lanka. Sevanatha Urban Resource Centre, Sri Lanka, 2000.

8. Jayaratne K. A. and Wanniarachch M. Urban Environmental Management through Community and Non-governmental Organizations. Ministry of Policy Planning and Implementation, Sri Lanka, 1992.

9. United Nations Centre for Human Settlements (Habitat). Shelter for Low-income Communities: Sri Lanka Demonstration Project-Case Study (Part-1). UNCHS, Nairobi, 1992.

10. United Nations Centre for Human Settlements (Habitat). Shelter for Low-income Communities: Sri Lanka Demonstration Project-Case Study (Part-II). United Nations, Nairobi, 1992.

11. Urban Development Authority. Colombo Metropolitan Regional Structure Plan. UDA, Sri Lanka, 1998.

12. Colombo Municipal Council and Sevanatha Urban Resource Centre. Poverty Profile-City of Colombo. Sevanatha, Sri Lanka, 2002.

13. Ministry of Local Government and Housing. Sri Lanka Policy Paper-Slum and Shanty Upgrading in Colombo Municipal Council. Ministry of Local Government, Colombo, 1979.

14. CARNEY D. (ed.) Sustainable Rural Livelihoods: What Contribution Can we Make? Department for International Development, London, 1998.

15. United Nations Centre for Human Settlements (Habitat). The Reformulation of Building Acts, Regulations and Codes in African Countries. UNHCS Habitat, Nairobi, 1985.

16. DuBors L. Valiant ladies; gendered dispositions in Argentine working class memories. Social Analysis, 1999, 43, No. 3.

17. GARR D. Expectative land rights, housing consolidation and cemetery squatting; some perspectives from Central Java. World Development, 1996, 24, No. 12, 1925-1933.

18. Rodriguez M. and Astrand J. Organised small-scale selfhelp housing. Building Issues, 1996, 8, No. 4, Habitat II.

19. Soliman A. M. Legitimising informal housing; accommodating low-income groups in Alexandria, Egypt. Environment and Urbanisation, 1996, 8, No. 1, April. 
20. Bassett E. M. and JACoBs H. M. Community-based tenure reform in urban Africa: the community land trust experiment in Voi, Kenya. Land Use Policy, 1997, 14, No. 3, 215-229.

21. United Nations Centre for Human Settlements (Habitat). Assessment of Experience with Project Approach to Shelter delivery for the Poor. United Nations, Nairobi, 1991.

22. Tipple A. G. and Ameen S. User initiated extension activity in Bangladesh; building slums or area improvement? Environment and Urbanisation, 1999, 11, No. 1.

23. Herzer H., Di Vrgilio M., Lanzetta M., Rodriguez M. and REDondo A. The formation of social organisations and their attempts to consolidate settlements and neighbourhoods undergoing transition in Buenos Aires. Environment and Urbanisation, 2000, 12, No. 1.

24. RAMSDELL L. National housing policy and the Favela in Brazil. In The Political Economy of Brazil (LAWRENCE S. and Austin R. (eds)). Austin University of Texas Press, 1990.

25. Bishop I., Escobar F. J., Karuppannan S., Williamson I. P., Yates P. M., Yaqub H. W. and Suwarnarat K. Spatial data infrastructure for cities in developing countries: lessons from the Bangkok experience. Cities, 2000, 17, No. 2, 85-96.
26. MAIA M. L. Land use regulations and rights to the city; squatter settlements in Recife, Brazil. Land Use Policy, 1995, 12, No. 2, 177-180.

27. Wood G. and Salway S. Introduction: securing livelihood in Dhaka slums. Journal of International Development, 2000, 12, 669-688.

28. Peattie L. R. An argument for slums. Journal of Planning Education and Research, 1994, 13, Part 2, 136-143.

29. Das M. Women and Urban Poverty in Guyana; A Profile of Some Squatter Settlements of Greater Georgetown. UNDP, Guyana, 1997.

30. BERNER E. Opportunities and insecurities; globalisation, localities and the struggle for urban land in Manila. European Journal of Development Research, 1997, 9, No. 1.

31. Mosha A. C. Evaluation of Botswana's strategies to regularise informal settlements. Review of Urban and Regional Development Studies, 1996, 8, No. 1, 46-65.

32. ОKPALA D. C. I. Upgrading slum and squatter settlements in developing countries; is there a cost effective alternative? Third World Planning Review, 1999, 21, No. 1.

\section{What do you think?}

To comment on this paper, please email up to 500 words to the editor at journals@ice.org.uk

Proceedings journals rely entirely on contributions sent in by civil engineers and related professionals, academics and students. Papers should be 2-5000 words long, with adequate illustrations and references. Please visit www.thomastelford.com/journals for author guidelines and further details. 